\title{
Environmental and economic benefits of variable rate nitrogen fertilization in a nitrate vulnerable zone
}

\author{
Bruno Basso a , Benjamin Dumont ${ }^{\mathrm{a}}$, Davide Cammarano ${ }^{\mathrm{b}}$, Andrea Pezzuolo ${ }^{\mathrm{c}}$, \\ Francesco Marinello ${ }^{c}$, Luigi Sartori ${ }^{c}$ \\ a Department of Geological Science and W.K. Kellogg Biological Station, Michigan State University, East Lansing, MI, USA \\ b James Hutton Institute, Dundee, Scotland, UK \\ c Department of Agroforesty and Landscape, University of Padua, Italy
}

\section{H I G H L I G H T S}

- The economic and environmental impact of Nitrogen fertilization was evaluated;

- Management zones were defined using spatio-temporal analysis of field characteristic and previous yields maps;

- Optimal $\mathrm{N}$ rates were defined through a modeling system approach (SALUS);

- Optimal $\mathrm{N}$ rates were applied within the field and validated through measurements over two successive years.

- Variable rate nitrogen reduced nitrate leaching and increased profit

\section{A R T I C L E I N F O}

\section{Article history:}

Received 5 November 2015

Received in revised form 19 December 2015

Accepted 21 December 2015

Available online $\mathrm{xxxx}$

Editor: D. Barcelo

\section{Keywords:}

Nitrate leaching

Nitrate-vulnerable area

Crop modeling

Yield maps

Environmental degradation

Variable rate nitrogen
GRAPH I C A L A B S T R A C T
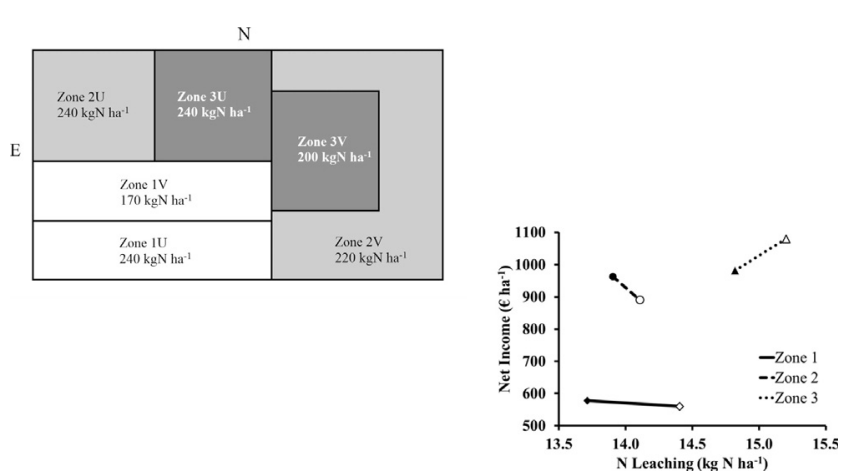

\begin{abstract}
A B S T R A C T
Agronomic input and management practices have traditionally been applied uniformly on agricultural fields despite the presence of spatial variability of soil properties and landscape position. When spatial variability is ignored, uniform agronomic management can be both economically and environmentally inefficient. The objectives of this study were to: i) identify optimal $\mathrm{N}$ fertilizer rates using an integrated spatio-temporal analysis of yield and site-specific $\mathrm{N}$ rate response; ii) test the sensitivity of site specific $\mathrm{N}$ management to nitrate leaching in response to different $\mathrm{N}$ rates; and iii) demonstrate the environmental benefits of variable rate $\mathrm{N}$ fertilizer in a Nitrate Vulnerable Zone. This study was carried out on a 13.6 ha field near the Venice Lagoon, northeast Italy over four years (2005-2008). We utilized a validated crop simulation model to evaluate crop response to different $\mathrm{N}$ rates at specific zones in the field based on localized soil and landscape properties under rainfed conditions. The simulated rates were: $50 \mathrm{~kg} \mathrm{~N} h a^{-1}$ applied at sowing for the entire study area and increasing fractions, ranging from 150 to $350 \mathrm{~kg} \mathrm{~N} \mathrm{ha}^{-1}$ applied at V6 stage. Based on the analysis of yield maps from previous harvests and soil electrical resistivity data, three management zones were defined. Two $\mathrm{N}$ rates were applied in each of these zones, one suggested by our simulation analysis and the other with uniform $\mathrm{N}$ fertilization as normally applied by the producer. $\mathrm{N}$ leaching was lower and net revenue was higher in the zones where variable rates of $\mathrm{N}$ were applied when compared to uniform $\mathrm{N}$ fertilization. This demonstrates the efficacy of using crop models to determine variable rates of $\mathrm{N}$ fertilization within a field and the application of variable rate $\mathrm{N}$ fertilizer to achieve higher profit and reduce nitrate leaching.

C 2015 Elsevier B.V. All rights reserved.
\end{abstract}




\section{Introduction}

Agronomic input and management practices have traditionally been applied uniformly on agricultural fields despite the spatial heterogeneity of soil properties and landscape position. When spatial variability is not taken into account, uniform agronomic management can be both economically and environmentally inefficient (Pierce and Nowak, 1999). Site-specific management (SSM) practices, proposed within the Precision Agriculture (PA) framework, gives farmers the possibility to increase yield, reduce inputs, and minimize environmental impact (Robert, 2002, Robertson et al., 2012; Basso et al., 2013). The potential benefits of SSM strategies are greatly dependent on the how accurately such variability can be assessed. Many authors have proposed guidelines for the delineation of management zones which can be defined as areas within a field that are homogeneous with regard to yield limiting factors (Mulla, 1991, Ferguson et al., 2004, Schepers et al., 2004, Chang et al., 2004; Basso et al., 2007; Basso et al., 2015). Pierce and Nowak (1999) highlighted how temporal and spatial variability of soil $\mathrm{N}$ has to be taken into account for successful SSM of $\mathrm{N}$ fertilization.

One of the most studied components of SSM is nitrogen (N) management. In areas where $\mathrm{N}$ fertilizer is cheap or subsidized, farmers tend to apply it in large quantities which can result in environmental problems including nitrate leaching, ammonia volatilization, nitrous oxide emissions or soil acidification (Grace et al., 2011). The pressure that over-fertilization exerts on the environment is getting more awareness as climate change and deterioration of fresh water become more critical. The European Union (EU), through the Nitrates Directive, aimed to preserve the quality of groundwater through a reduction of $\mathrm{N}$ fertilizer by promoting good farming practices (91/676/ $\mathrm{EEC}$ ).

Despite technological advances in monitoring plant $\mathrm{N}$ status, determining the optimum $\mathrm{N}$ amount necessary within each uniform management zone in a field remains a daunting task due to the large spatial and temporal variation that these variables exert at the field scale. Plant response to variable management levels is highly dependent upon the weather that occurs during a given growing season (Basso et al., 2007; Basso et al., 2013; Dumont et al., 2014, 2015a). For example, crop response to $\mathrm{N}$ in rainfed environments may be high when water is available, or low when the soil water content is limited (Basso et al., 2011a). However farmers must make decisions about $\mathrm{N}$ application based on developmental stages of crop growth without foreknowledge of the kind of weather that will occur after fertilizer application. Since future weather conditions are unknown, a risk management strategy needs to be adopted to verify the impact of $\mathrm{N}$ fertilizer over a long enough period of time (i.e., 30 years) in order to represent the diversity of climate and soil interactions that are present. The biggest challenge of such an approach is the development of a yield response function that can represent a crop's response to the $\mathrm{N}$ rate management and other interactions (Basso et al., 2011b, Dumont et al., 2013, 2015b).

Process oriented crop simulation models integrate the effects on crop growth of multiple stress interactions over time and under different environmental and management conditions (Batchelor et al., 2002; Basso et al., 2013). However their application in PA can be limited because simulations cannot be performed everywhere in a field given that the availability of detailed (soil and crop data) inputs is limited and the costs are prohibitive. Basso et al. (2007) used a more balanced approach to study spatial and temporal variability of crop behavior in a field when they applied a crop simulation model for SSM. They considered temporal stability and spatial variability of measured yield maps to delineate stable or unstable spatial patterns and identify zones of similar crop performance. Then they performed model evaluations at selected sites within each of the management zones. In another study Basso et al. (2011a) presented a tactical and strategic procedure for selection of optimal $\mathrm{N}$ fertilizer rates to be applied on management zones identified as homogenous based on the outputs of a crop simulation model and the simulated levels of plant available soil water at the time of the second $\mathrm{N}$ application. In this study we simply hypothesized that variable rate nitrogen fertilizer when properly identified in terms of quantity and spatial distributions leads to higher profit and lower environmental impact.

The objectives of this study was to demonstrate the advantages of variable rate management with a field study where variable and business-as-usual nitrogen rate were compared with field measured data of yield and farmers' revenues. To achieve the objective of the study, (i) uniform management zone were identified using an integrated spatio-temporal analysis; (ii) optimal $\mathrm{N}$ fertilizer rates were determined on the basis of simulated yield and $\mathrm{N}$-leaching responses to the sitespecific $\mathrm{N}$ rates; (iii) the so-defined optimum $\mathrm{N}$ rates were physically applied within each zone of the field; and (iv) the economic and environmental benefits of variable rate $\mathrm{N}$ fertilizer in a Nitrate Vulnerable Zone was finally demonstrated through a comparison to the businessas-usual practice and the subsequent validation measurements.

\section{Materials and methods}

\subsection{Site description}

This study was carried out on a 13.6 ha field near the Venice Lagoon, NE Italy $\left(45^{\circ} 22^{\prime} 23.02^{\prime \prime} \mathrm{N}, 12^{\circ} 08^{\prime} 24.27^{\prime \prime} \mathrm{E},-2 \mathrm{~m}\right.$ a.s.l) for the 2005,2006 , 2007, and 2008 growing seasons. The area was identified as a Nitrate Vulnerable Zone (NVZ) according to Nitrate Directive 91/676 (EEC, 1991) because high potential nitrate leaching in ground and surface waters. Soil texture varies greatly in the study area, ranging from sandy to silty-loam (Soil Survey Staff, 1999). Daily weather data were collected by an automatic meteorological station located near the experimental field (ARPAV, Bureau of Meteorology of Veneto Region).

\subsection{Agronomic management}

The agronomic practices applied to the crops included in this study are representative for the growing area. Crop rotation adopted was sugar beet in 2005 and continuous maize for the remaining three years. A detailed explanation of the agronomic practices applied for the 2007 and 2008 growing seasons are shown in Table 1.

\subsection{Soil sampling}

An extensive characterization of soil in the study area was made in 2005. A mixed-sampling scheme of the top soil layer $(0-30 \mathrm{~cm})$ was followed based on a regular grid: 40 samples were collected at the nodes of a $60-\mathrm{m}$ grid and 80 additional points were collected at the nodes of 10 transects, resulting in a total of 120 samples. Transects were set in the north and east axis at 1, 5, 15, $30 \mathrm{~m}$ from 10 randomly chosen nodes of the grid. Soil texture was determined using the hydrometer method (Klute and Dirkens, 1986), soil bulk density was measured with the core method (Grossman and Reinsch, 2002) and soil $\mathrm{pH}$ and electric conductivity were measured with a $\mathrm{pH} / \mathrm{EC}$ tester on a soil water extract. Organic carbon was measured using the Walkley-Black method (Walkley and Black, 1934) and the results converted to organic matter by multiplying the carbon percentage by 1.72 . Total $\mathrm{N}$ was determined using Kjedahl method and labile phosphorus was determined with the Olsen method. In addition, spatial soil electric conductivity $\left(E_{\mathrm{a}}\right)$ was measured with an EMI sensor (Geonics EM38DD) which determined conductivity in both horizontal and vertical orientations. This instrument provided a weighted depth reading to approximately $0.5 \mathrm{~m}$ in the horizontal orientation and $1.5 \mathrm{~m}$ in the vertical orientation. $\mathrm{EC}_{\mathrm{a}}$ measurements were collected in November 2005, carried out in the field with associated DGPS antenna. 
Table 1

Agronomic management for Maize for the growing season 2007 and 2008.

\begin{tabular}{|c|c|}
\hline Dates & Agronomic management \\
\hline $05-10-06$ & Sowing of cover crop (Horseradish - Armoracia rusticana; $25 \mathrm{~kg} \mathrm{ha}^{-1}$ ) \\
\hline $14-03-07$ & Chopping of cover crop \\
\hline $29-03-07$ & Weed control (glyphosate $8.61 \mathrm{ha}^{-1}$ and thifensulfuron $10 \mathrm{~g} \mathrm{ha}^{-1}$ ) \\
\hline $12-04-07$ & Non-inversion tillage (30 cm depth) \\
\hline $23-04-07$ & $\begin{array}{l}\text { First } \mathrm{N} \text { fertilization }\left(50 \mathrm{~kg} \mathrm{~N} \mathrm{ha}^{-1}\right) \text { - Liquid Ammonium Sulfate } \\
(20-0-0)\end{array}$ \\
\hline $26-04-07$ & Planting (Dekalb DKC6040; 7.5 plants $\mathrm{m}^{-2}$ ) \\
\hline $28-04-07$ & Weed control (Flufenacet $1.21 \mathrm{ha}^{-1}$ ) \\
\hline $01-06-07$ & P fertilizing $\left(12.5 \mathrm{~kg} \mathrm{ha}^{-1}\right)$ \\
\hline 01-06-07 & $\begin{array}{l}\text { Second N fertilization (variable rate, see M\&M) - Liquid Ammonium } \\
\text { Sulfate }(20-0-0)\end{array}$ \\
\hline $17-07-07$ & Insecticide treatment (Deltamethrin $0.51 \mathrm{ha}^{-1}$ ) \\
\hline $20-07-07$ & Irrigation (50 mm) - Sprinkler \\
\hline $17-09-07$ & Harvest \\
\hline $11-10-07$ & Sowing of cover crop (Horseradish - Armoracia rusticana; $25 \mathrm{~kg} \mathrm{ha}^{-1}$ ) \\
\hline $31-03-08$ & Chemical cover crop control \\
\hline $31-03-08$ & $\begin{array}{l}\text { First } \mathrm{N} \text { fertilization ( } 50 \mathrm{~kg} \mathrm{~N} \mathrm{ha}^{-1} \text { ) - Liquid Ammonium Sulfate } \\
(20-0-0)\end{array}$ \\
\hline $29-04-08$ & Shallow tillage \\
\hline $30-04-08$ & Planting (Dekalb DKC6040; 7.5 plants $\mathrm{m}^{-2}$ ) \\
\hline $30-04-08$ & P fertilizing (12.5 $\left.\mathrm{kg} \mathrm{ha}^{-1}\right)$ \\
\hline $02-05-08$ & Weed control (Flufenacet $1.2 \mathrm{l} \mathrm{ha}^{-1}$ and Florasulam $11 \mathrm{ha}^{-1}$ ) \\
\hline $27-05-08$ & Weed control (Foramsulfuron $2.5 \mathrm{l} \mathrm{ha}^{-1}$ ) \\
\hline $11-06-08$ & $\begin{array}{l}\text { Second N fertilization (variable rate, see M\&M) - Liquid Ammonium } \\
\text { Sulfate }(20-0-0)\end{array}$ \\
\hline $11-09-08$ & Harvest \\
\hline
\end{tabular}

\subsection{Yield monitoring}

Yield data were recorded by a NewHollandTX64 combine harvester equipped with a yield monitor system (grain mass flow and moisture sensors). Site coordinates for each yield measurement were determined with a differentially corrected (OMNISTAR signal) Trimble 132 receiver The SMS software version 3.0TM (AgLeader Technology, Inc.) was used to read the row yield data (expressed at $14 \%$ dry matter).

\subsection{Methodology for identification of uniform management zones}

The procedure to identify the management zones for this field are described in Chiericati et al. (2007). Homogeneous zones were delineated by considering harvested yield levels measured within areas of the field for the first two years (sugarbeet in 2005 and maize in 2006), the degree of stability of those yield levels over time, measured soil properties (sand, clay and organic matter) and the map of soil electrical resistivity obtained in the horizontal orientation. An overlay of all these data layers was performed using a Fuzzy C-means method (Chiericati et al., 2007).

Geostatistical analyses were performed for each of the measured variables. Spatial structure of the data was assessed developing semivariograms with the use of GS + software version 9.0 (Gamma Design Software, 2009). The best fit model selection for experimental semivariogram was done by the "leaving-one-out" method of crossvalidation and spatial interpolation was carried out using the kriging technique. Spatial dependence was determined for each soil and crop variable and spatial maps were drawn using Surfer v 6.0 (Golden Software, 1995). The Fuzziness Performance Index (FPI) was used to measure the degree of separation between classes (Fridgen et al., 2004). FPI is an index ranging from 0 to 1 , which values approaching 0 indicate distinct classes with low sharing, while values near 1 indicate non-distinct classes with a large degree of property sharing. More details about the procedure can be found in Chiericati et al. (2007) and Basso et al. (2007).

\subsection{Crop growth model and simulation scenarios}

Simulation runs were performed using the SALUS model. The SALUS model is a process-oriented system that simulates plant growth and development responses to environmental conditions (soil and weather), genetics and management strategies in a sequential mode (Basso and Ritchie, 2015).

Weather data used by the models included daily values of incoming solar radiation $\left(\mathrm{MJ} \mathrm{m}^{-2}\right.$ day $\left.^{-1}\right)$, maximum and minimum air temperature $\left({ }^{\circ} \mathrm{C}\right)$ and rainfall $(\mathrm{mm})$. Soil input data used by the model include silt and clay content, bulk density, organic carbon, soil hydraulic properties, initial soil water and nitrogen contents. Data were all measured on site (Table 3) and soil hydraulic properties were calculated using the procedure suggested by Ritchie et al. (1999). The SALUS model has been widely validated for maize yields and nitrogen leaching under variable $\mathrm{N}$ fertilizer rates in the study area, as reported in Basso et al. (2007, 2010, 2011a, 2011b, 2012); Bertocco et al. (2008) and Pezzuolo et al. (2014).

Long-term simulation scenarios were created for each zone under rainfed conditions with $50 \mathrm{~kg} \mathrm{~N} \mathrm{ha}^{-1}$ applied at sowing and five different $\mathrm{N}$ fertilization rates considered for the second application and applied at V6 stage: $150,200,250,300,350 \mathrm{~kg} \mathrm{~N}^{-1}$. For each of the zones previously identified, the model was run with these five $\mathrm{N}$ rates using long-term weather data, and results were then averaged over years. The optimal $\mathrm{N}$ rates were determined for each zone considering the simulated yield and $\mathrm{N}$ leaching expected in each of these zones, as described in the Results section.

Each management zone was then divided into two sub-units and each sub unit was fertilized according two different treatments during two growing seasons (2007 and 2008). The first sub-unit of each zone was fertilized uniformly (U) according to the business-as-usual management practice. The second sub-unit received a variable rate $(\mathrm{V})$ within each zone, chosen from the model simulation results obtained in each area.

\subsection{Model and field outputs analysis}

The marginal value of $\mathrm{N}$ fertilization was calculated from the simulated data. Net income ( $\mathrm{NI}$ ) was calculated by considering maize yields $\left(Y_{M}\right)$, selling prices $\left(M_{p}\right)$, the costs associated to the strategy of $N$ fertilization $\left(\mathrm{N}_{\text {fer }}\right)$ and $\mathrm{N}$ price $\left(\mathrm{N}_{\mathrm{P}}\right)$ as follows:

$\mathrm{NI}=\left(\mathrm{Y}_{\mathrm{M}} \times \mathrm{M}_{\mathrm{p}}\right)-\left(\mathrm{N}_{\text {fer }} \times \mathrm{N}_{\mathrm{p}}\right)$

In this paper $M_{p}$ was fixed at $0.135 € \mathrm{~kg}^{-1}$ and $\mathrm{N}_{\mathrm{P}}$ was fixed at $0.93 € \mathrm{~kg}^{-1}$ (current prices for fertilizer and wheat grains).

The marginal value (MV) is defined here as the change in net income in terms of the change in $\mathrm{kg} \mathrm{N}^{-1}$ applied. It is calculated as follows:

$\mathrm{MV}=\frac{\Delta \mathrm{NI}}{\Delta \mathrm{N}_{\mathrm{fer}}}$

where $\Delta \mathrm{NI}$ is the difference between two levels of net income ( $€ \mathrm{ha}^{-1}$ ) and $\Delta \mathrm{N}_{\text {fer }}$ is the difference between two levels of fertilization $\left(\mathrm{kg} \mathrm{Nha}^{-1}\right)$. That way, MV is the derivative of NI, for which a value of zero corresponds to the optimum of the NI curve.

In the same way, differential $\mathrm{N}$ leaching $\left(\mathrm{dN}_{\text {leach }}\right)$ was computed as the change in the amount of $\mathrm{N}$ leached $\left(\Delta \mathrm{N}_{\text {leach }}\right)$ in terms of the change in additional units of $\mathrm{N}$ fertilization $\left(\Delta \mathrm{N}_{\mathrm{fer}}\right)$ as follows:

$\mathrm{dN}_{\text {leach }}=\frac{\Delta \mathrm{N}_{\text {leach }}}{\Delta \mathrm{N}_{\text {fer }}}$

The slope of the linear regression derived on the $\mathrm{dN}_{\text {leach }}$ data offers an appreciation of the risk of $\mathrm{N}$ leaching. Optimal $\mathrm{N}$ strategies were determined for each zone on the basis of a concomitant analysis of MV and 
a)

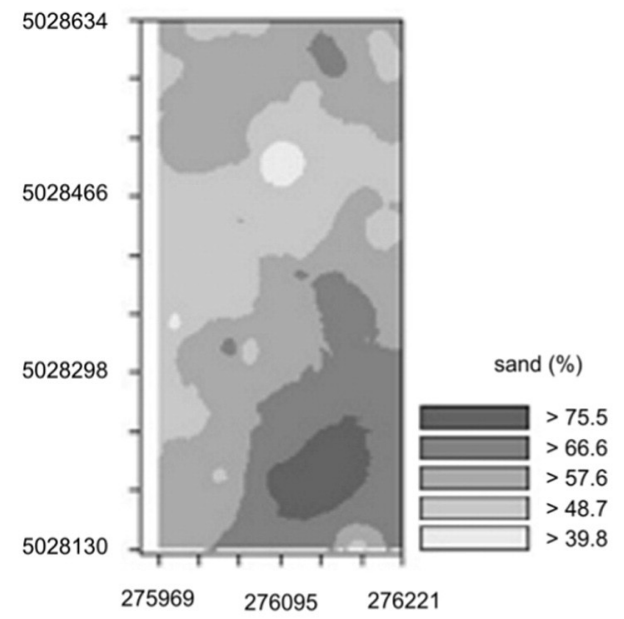

E

c)

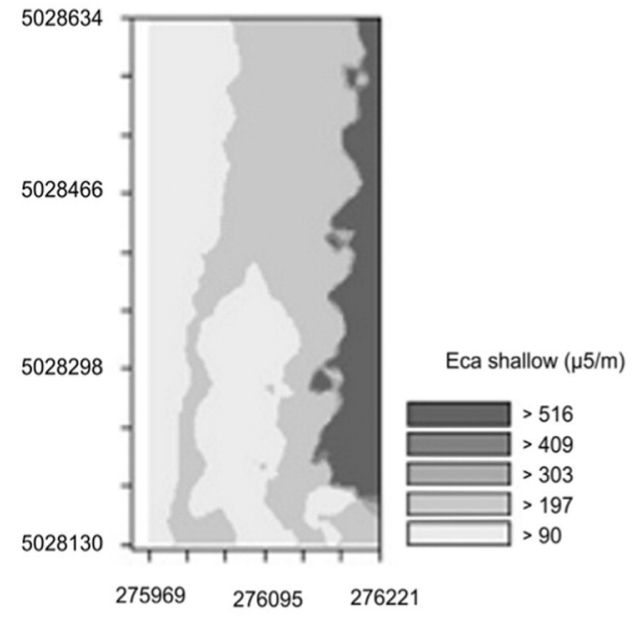

b)

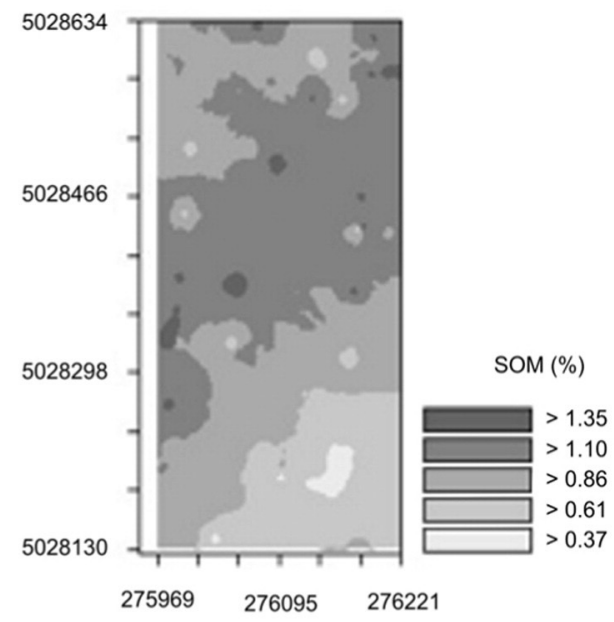

$\mathrm{E}$

d)

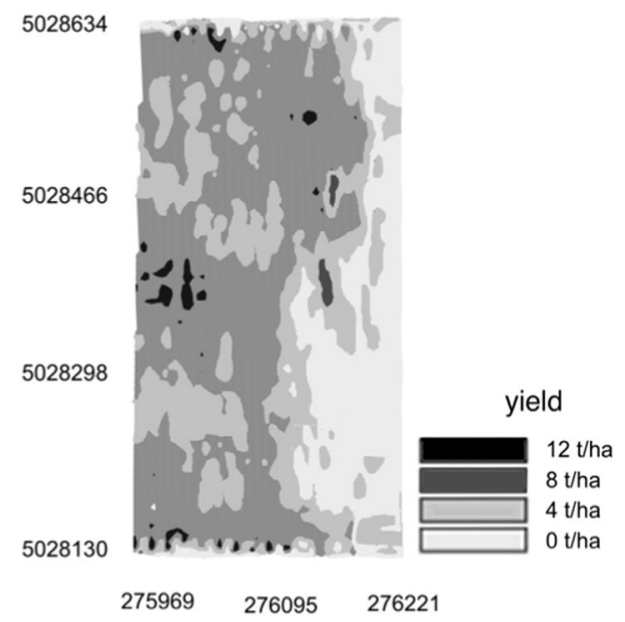

E

$\mathrm{E}$

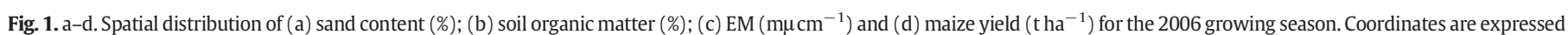
using the UTM systems (Easting and Northing).

$\mathrm{dN}_{\text {leach }}$ and these rates were then applied in fields for the 2007 and 2008 growing seasons.

At the zone level, field experiment outputs obtained with the uniform and the variable $\mathrm{N}$ rates could be compared on the basis of their average values. However, to allow a proper analysis at the field scale, a more relevant approach consists of computing the geometrical average (GAvg). Geometrical averages of yield ( $\left.\mathrm{Y}_{\mathrm{GAvg}}\right)$ and net income at the field scale $\left(\mathrm{NI}_{\mathrm{GAvg}}\right)$ were calculated with the following equations:

$\mathrm{Y}_{\mathrm{GAvg}}=\frac{\sum_{\mathrm{i}=1}^{3}\left(\mathrm{Y}_{\mathrm{Zi}} \times \mathrm{A}_{\mathrm{Zi}}\right)}{\sum_{\mathrm{i}=1}^{3}\left(\mathrm{~A}_{\mathrm{Zi}}\right)}$

$\mathrm{NI}_{\mathrm{GAvg}}=\frac{\sum_{\mathrm{i}=1}^{3}\left(\mathrm{Y}_{\mathrm{Zi}} \times \mathrm{A}_{\mathrm{Zi}} \times \mathrm{M}_{\mathrm{p}}\right)-\sum_{\mathrm{i}=1}^{3}\left(\mathrm{~N}_{\mathrm{fer} \mathrm{Zi}} \times \mathrm{A}_{\mathrm{Zi}} \times \mathrm{N}_{\mathrm{p}}\right)}{\sum_{\mathrm{i}=1}^{3}\left(\mathrm{~A}_{\mathrm{Zi}}\right)}$

where $\mathrm{Y}_{\mathrm{Zi}}$ and $\mathrm{N}_{\text {fer } \mathrm{Zi}}$ are yield and fertilization rate applied in zone $\mathrm{i}$ of area $A_{Z i}$. To allow a fair comparison at the field scale of the results obtained with the variable and uniform $\mathrm{N}$ application rates, $\mathrm{A}_{\mathrm{Zi}}$ values were computed as the mean area of the variable and uniform zones for each $i$ zone. In that way, $A_{z 1}$ is the mean of the zone 1 area where the variable $\mathrm{N}$ rate was applied and the zone 1 area where the uniform $\mathrm{N}$ rate was applied.

\section{Results}

Maps of soil physical and chemical properties showing spatial variability are shown in Fig. 1a-c. The south-eastern portion of the field was characterized by high sand content with values ranging between 66 and 75\% while lower values of sand content $(<40 \%)$ were found in the northern portion (Fig. 1a). Soil Organic Matter (SOM) ranged between $0.35 \%$ and $1.36 \%$ with higher values in a transect in the midnorthern portion of the field and lower values in the south-eastern part (Fig. 1b). Fig. 1c shows higher EC values in the southern portion of the study area and lower values in the northern portion. Fig. 1d is a maize yield map for the 2006 growing season. There was a general North-South gradient in yields for this particular year. High yield values were obtained in the north-western portion of the study area (between

\section{Table 2}

Correlation between soil parameters and sugarbeet yield and sugar content according to $\mathrm{EC}_{\mathrm{a}}$ and RVI. "*' accounts for correlations that are significant at the $5 \%$ level. Adapted from Chiericati et al. (2007).

\begin{tabular}{llllll}
\hline & Sand & Clay & O.M. $^{\mathrm{a}}$ & Yield & Sugar \\
\hline $\mathrm{EC}_{\mathrm{a}}$ & +0.035 & -0.024 & +0.138 & $-0.313^{*}$ & $+0.333^{*}$ \\
$\mathrm{RVI}$ & $-0.516^{*}$ & $+0.388^{*}$ & $+0.288^{*}$ & $+0.265^{*}$ & $-0.236^{*}$ \\
\hline
\end{tabular}




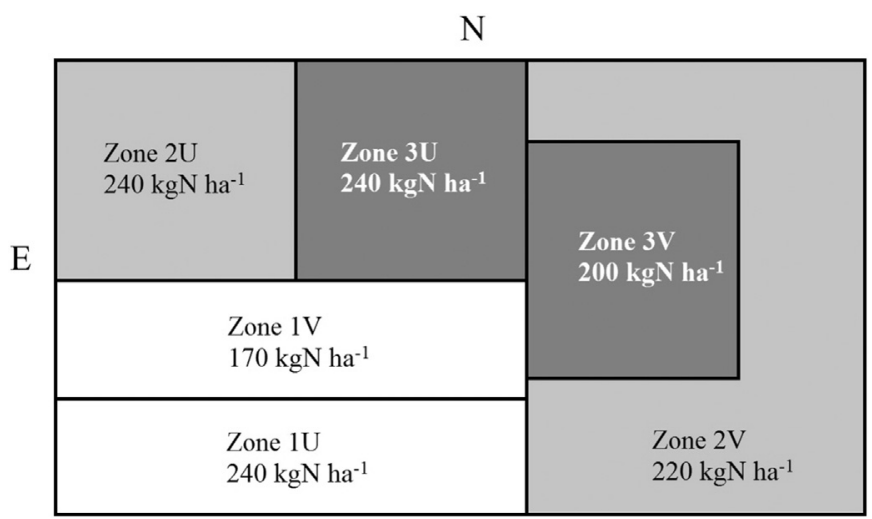

Fig. 2. Delineation of uniform management zones; $\mathrm{N}$ was applied on each zone as variable application (V) and as uniform application (U). Below each zone is reported the amount of $\mathrm{N}$ applied.

8 and $12 \mathrm{tha}^{-1}$ ) characterized by higher SOM; and low yield values were found in the south-eastern portion, where soil fertility was lower.

Table 2 reports correlations coefficient between soil parameters and sugar beet yield (dry mater and sugar content measured in 2005) according to $\mathrm{EC}_{\mathrm{a}}$ values and the Ratio Vegetation Index (RVI - ratio of the red and near-infrared reflectance measured) that was measured on July 15th, 2005. RVI was used in 2005 to account for plant vigor and derive the yield map of sugar beet (Chiericati et al., 2007). Soil parameters were significantly correlated with RVI but not with $\mathrm{EC}_{\mathrm{a}}$. Yield and sugar content were correlated with both $\mathrm{EC}_{\mathrm{a}}$ and RVI.

Three management zones were identified within the field (Fig. 2) using the spatio-temporal analysis depicted at Section 2.5. With the imposition of 3 management zones, FPI values ranged between 0.125 with a parameter set including only soil characteristics and $\mathrm{EC}_{\mathrm{a}}$, and 0.325 with a parameter set including soil characteristics, $\mathrm{EC}_{\mathrm{a}}$ and yield maps (2005-2006). The low FPI values characterized a confident delineation of zones, confirmed by the similarity patterns obtained under both parameter sets (Chiericati et al., 2007). Zone 1 encompasses the southeastern portion of the field and is characterized by an average clay content of $6.9 \%$, sand content of $71.7 \%$, OM of $0.7 \%$ and average maize yield of $5.15 \mathrm{t} \mathrm{ha}^{-1}$ observed for 2006 (Table 3 ). Zone 2 is characterized by clay, sand and OM contents of $15.1 \%, 52.7 \%$ and $1 \%$, respectively and average maize yields of $7.32 \mathrm{t} \mathrm{ha}^{-1}$. Zone 2 encompasses the southwestern and northern portions of the field. The remaining portions of the field, designated Zone 3, are characterized by the highest clay content (29.6\%), the lowest sand content (33.4\%), an OM content of $1.1 \%$ and an average maize yield of $9.21 \mathrm{tha}^{-1}$ (Table 3 ). On the basis of its soil properties, Zone 1 had the lowest water holding capacity (high sand and low clay contents) and the lowest fertility (low SOM content). On contrary, Zone 3 was characterized by a high water holding capacity and a higher soil SOM.

The SALUS model was run for 30-years for each of the three zones at the five different $\mathrm{N}$ rates. Model outputs were averaged over years and results are shown in Fig. 3a-b. Overall maize yield is higher for Zone 3 and lower for Zone 1. In Zone 1 maize yield increased from 6.15 to $7.9 \mathrm{t} \mathrm{ha}^{-1}$ for $\mathrm{N}$ fertilization rates between $150 \mathrm{~kg} \mathrm{~N} \mathrm{ha}^{-1}$ and
$350 \mathrm{~kg} \mathrm{~N} \mathrm{ha}^{-1}$. In Zone 2 maize yield increased from 6.8 to $8.1 \mathrm{t} \mathrm{ha}^{-1}$ for the same rates and in Zone 3 it slightly increased from $7.75 \mathrm{tha}^{-1}$ and reached a plateau of $8.6 \mathrm{t} \mathrm{ha}^{-1}$ at $300 \mathrm{~kg} \mathrm{~N} \mathrm{ha}^{-1}$ (Fig. 3a). The relationship between simulated $\mathrm{N}$ leaching and $\mathrm{N}$ fertilization rate is shown in Fig. 3b. The overall trend shows that $\mathrm{N}$ loss due to leaching increased as $\mathrm{N}$ fertilization rate increased (Fig. 3b). Zone 2 had the lowest values of $\mathrm{N}$ leaching which ranged between 13.5 to $14.8 \mathrm{~kg} \mathrm{~N}^{-1}$ while $\mathrm{N}$ leaching in zone 3 ranged between 14.4 to $15.8 \mathrm{~kg} \mathrm{~N} \mathrm{ha}^{-1}$ (Fig. 3b).

The marginal values of $\mathrm{N}$ fertilization for the three zones are shown in Fig. 3c. Marginal values for Zone 1 were positive below $300 \mathrm{~kg} \mathrm{~N} \mathrm{ha}^{-1}$ of $\mathrm{N}$ applied and negative after application of $300 \mathrm{~kg} \mathrm{~N} \mathrm{ha}^{-1}$. $\mathrm{N}$ fertilizer rates higher than $250 \mathrm{~kg} \mathrm{~N} \mathrm{ha}^{-1}$ in Zone 2 were all characterized by a negative marginal value. In Zone 3 all marginal values were below the zero thresholds, except for $150 \mathrm{~kg} \mathrm{~N}^{-1}$. The standard deviations on simulations were not reported here to increase figure readability, but it is worth noting that they had an impact on the determination of the optimal $\mathrm{N}$ rate.

With regard to the risk of $\mathrm{N}$ leaching (Fig. 3d), Zones 2 and 3 had the lowest $\mathrm{dN}_{\text {Leach }}$ values with linear regression slopes that equaled 0.0008 and $4.10^{-5}$, respectively. Zone 1 had the highest percent of nitrate leaching losses values and exhibited the highest linear regression slope (0.0011), offering the highest risk of increasing $\mathrm{N}$ leaching as $\mathrm{N}$ fertilization increased.

On the basis of these results, different $\mathrm{N}$ rates were selected for each zone (Table 4 and Fig. 2). The integrated and in depth analysis of the reasons that led to the $\mathrm{N}$ rate selection is presented in the Discussion section. For the sub-unit of Zones 1, 2 and 3 that received variable $\mathrm{N}$ rate (Zones $1 \mathrm{~V}, 2 \mathrm{~V}$ and $3 \mathrm{~V}$ on Fig. 2), the $\mathrm{N}$ fertilizer rates were $170 \mathrm{~kg} \mathrm{~N} \mathrm{ha}^{-1}, 220 \mathrm{~kg} \mathrm{~N} \mathrm{ha}^{-1}$, and $200 \mathrm{~kg} \mathrm{~N}^{-1}$, respectively. The business-as-usual fertilization regimen consisted of $240 \mathrm{~kg} \mathrm{~N}^{-1}$. For all zones and rates, $\mathrm{N}$ application was split with $50 \mathrm{~kg} \mathrm{~N} \mathrm{ha}^{-1}$ applied at sowing and the remaining amount applied before elongation (Table 4).

Maps of measured maize yield for the 2007 and 2008 growing seasons are shown in Fig. 4a-b. Table 5 shows the results of the averaged maize yield per zone and subsequent net incomes for the 2007 and 2008 growing seasons and for the two different $\mathrm{N}$ strategies. In Zone 1 the sub-unit with $170 \mathrm{~kg} \mathrm{~N}^{-1}$ showed observed maize yields of $4.3 \mathrm{t} \mathrm{ha}^{-1}$ in 2007 and $6.6 \mathrm{t} \mathrm{ha}^{-1}$ in 2008 compared to 4.3 and $7.3 \mathrm{t} \mathrm{ha}^{-1}$ for the uniform $\mathrm{N}$ fertilization. In Zone 2 the sub-unit with variable $\mathrm{N}$ rate showed a maize yield of 7.1 and $10.2 \mathrm{t} \mathrm{ha}^{-1}$ for the 2007 and 2008 growing seasons, respectively. The Zone 2 sub-unit with uniform $\mathrm{N}$ application showed a maize yield of $6.7 \mathrm{t} \mathrm{ha}^{-1}$ in 2007 and $9.8 \mathrm{t} \mathrm{ha}^{-1}$ in 2008 (Table 5). Zone 3 recorded 7.4 and $9.9 \mathrm{t} \mathrm{ha}^{-1}$ for the sub-unit with variable $\mathrm{N}$ for the 2007 and 2008 growing seasons, respectively. The Zone 3 sub-unit with uniform N management showed maize yields of 8.2 and $11.1 \mathrm{t} \mathrm{ha}^{-1}$ for the 2007 and 2008 growing season (Table 5).

The overall arithmetic average maize yield of the two growing seasons and for the sub-units with variable $\mathrm{N}$ management was $7.58 \mathrm{tha}^{-1}$ while the average maize yield for the uniform $\mathrm{N}$ management was $7.9 \mathrm{tha}^{-1}$ (Table 5). The relative difference equaled $-4.0 \%$, relative to uniform management areas. However, the geometrical field scale average where variable $\mathrm{N}$ rates were applied equaled $7.76 \mathrm{t} \mathrm{ha}^{-1}$ while it equaled $7.95 \mathrm{t} \mathrm{ha}^{-1}$ under uniform treatment, leading to a much lower relative difference of $-2.3 \%$.

Table 3

Zone averaged soil physical and chemical properties, and maize yield observed in 2006 .

\begin{tabular}{|c|c|c|c|c|c|c|c|c|c|}
\hline & $\begin{array}{l}\text { Clay } \\
(\%)\end{array}$ & $\begin{array}{l}\text { Silt } \\
(\%)\end{array}$ & $\begin{array}{l}\text { Sand } \\
(\%)\end{array}$ & $\begin{array}{l}\text { O.M. }^{\mathrm{a}} \\
(\%)\end{array}$ & $\begin{array}{l}\text { B.D. }^{\mathrm{b}} \\
\left(\mathrm{g} \mathrm{cm}^{-3}\right)\end{array}$ & $\mathrm{pH}$ & $\begin{array}{l}\mathrm{EC}_{\mathrm{a}} \\
\left(\mu \mathrm{S} \mathrm{cm} \mathrm{cm}^{-1}\right)\end{array}$ & $\begin{array}{l}N_{\text {init }} \\
(\%)\end{array}$ & $\begin{array}{l}\text { Maize yield } \\
\left(\mathrm{t} \mathrm{ha}{ }^{-1}\right)\end{array}$ \\
\hline Zone 1 & 6.9 & 21.4 & 71.7 & 0.7 & 1.6 & 7.3 & 415.8 & 0.061 & 5.15 \\
\hline Zone 2 & 15.1 & 32.2 & 52.7 & 1.0 & 1.5 & 7.3 & 633.4 & 0.092 & 7.32 \\
\hline Zone 3 & 29.6 & 37.1 & 33.4 & 1.1 & 1.7 & 7.0 & 462.0 & 0.069 & 9.21 \\
\hline
\end{tabular}

\footnotetext{
a O.M.: Organic matter.
}

b B.D.: Bulk density. 

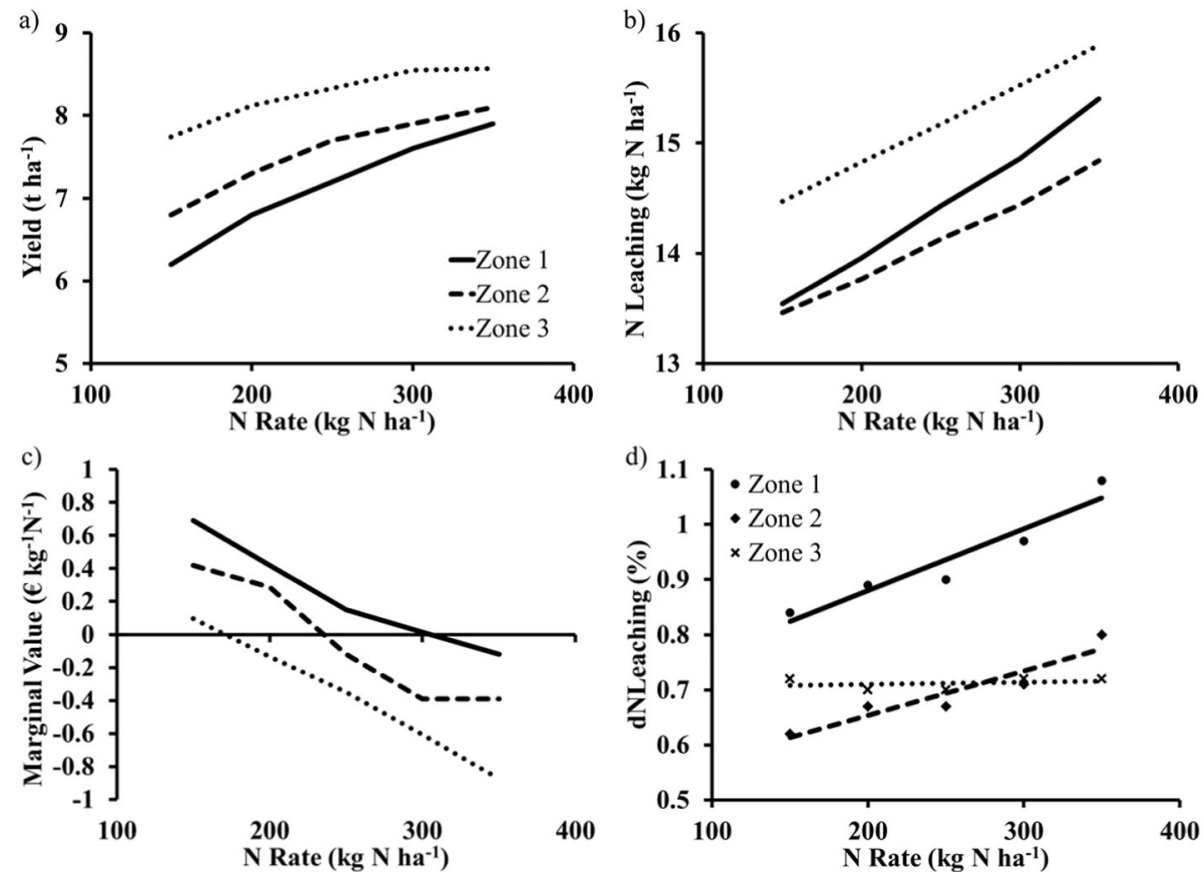

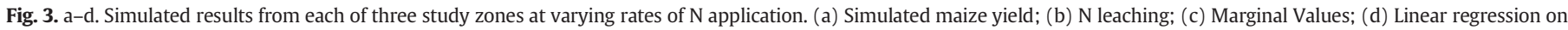
$\mathrm{dN}_{\text {leach }}$ values (RRMSE between linear regressions and observations equaled 2.7\%, $2.9 \%$ and $1.3 \%$, respectively for zone 1,2 and 3 ).

Net return was higher for uniform $\mathrm{N}$ rates for Zone 3 with a difference of $98 € \mathrm{ha}^{-1}$ with respect to variable $\mathrm{N}$ management (Table 5). For the Zones 1 and 2, the variable $\mathrm{N}$ fertilization rate gave respectively 58 and $73 € \mathrm{ha}^{-1}$ net returns more than the uniform $\mathrm{N}$ fertilization. The arithmetic average resulted in a $-0.29 \%$ relative net revenue loss for SSM. However, when the geometrical averages were computed, the overall net revenue at the field scale was only $849 € \mathrm{ha}^{-1}$ under uniform $\mathrm{N}$ management, while it reached $861 € \mathrm{ha}^{-1}$ under variable $\mathrm{N}$ management. In other words, SSM offered a $+1.36 \%$ increase in net revenue per hectare.

Fig. 5 reports the measured soil $\mathrm{N}-\mathrm{NO}_{3}^{-}$content averaged over the crop seasons 2007 and 2008 for each zone and each fertilizer treatment, as well as the averaged over the whole field for the two treatments. In zone 1 and 3, the variable rate treatment systematically gave lower $\mathrm{N}-$ $\mathrm{NO}_{3}^{-}$contents in the soil solution. In particular, zone 3 showed a high $\mathrm{N}-\mathrm{NO}_{3}^{-}$content during crop season 2008 under the uniform rate compared to the variable treatment. Zone 2 reported opposite results, and the zone where variable management was practiced exhibited a higher soil N-NO${ }_{3}^{-}$concentration compared to the business-as-usual rate. The relative difference between the two zones decreased from 36\% to 30\% between 2007 and 2008. Globally, over years and zones, variable management treatment showed an averaged concentration of $55 \mathrm{ppm}$, while uniform rate exhibited an averaged $64 \mathrm{ppm}$ concentration (16\% higher).

Fig. 6 shows the relationship between the simulated $\mathrm{N}$ leaching (averaged over 30 years) and the net return (average of observations in 2007-2008) for each zone, and for variable and uniform N management. In all three zones studied, uniform $\mathrm{N}$ management caused higher
$\mathrm{N}$ leaching than the variable $\mathrm{N}$ application. This finding is a significant finding because it demonstrates the when $\mathrm{N}$ fertilizer rate is properly chosen, it minimizes nitrate leaching without affecting net revenue. The highest net revenues obtained in zone 3 under uniform management were negatively offset by higher $\mathrm{N}$ leaching which contributes to environmental degradation. The highest $\mathrm{N}$ leaching values were obtained for Zone 3 under uniform $\mathrm{N}$ management with $15.2 \mathrm{~kg} \mathrm{~N} \mathrm{ha}^{-1}$; while under variable $\mathrm{N}$ application the same zone showed leaching values of $14.8 \mathrm{~kg} \mathrm{~N}^{-1}$ (Fig. 5). In both Zones 1 and 2, net incomes were higher under the variable $\mathrm{N}$ management and $\mathrm{N}$ leaching was lower.

\section{Discussion}

Spatial variability is not usually considered by farmers at the time of second $\mathrm{N}$ fertilization and they generally apply a uniform $\mathrm{N}$ rate in the study area of about $240(50+190) \mathrm{kg} \mathrm{N} \mathrm{ha}^{-1}$ across a field. The strength of a system approach lays in the fact that the interaction between soil, weather, management and genetics can be taken into account when dealing with a complex aspect such as the decision of the $\mathrm{N}$ fertilizer to apply and the lack of knowledge site-specific response of a crop at various $\mathrm{N}$ levels over a long period of time. The long term simulations with different weather allow to capture the ranges of yield responses to nitrogen rates and choose the optimal rate that more frequently provides the best outcomes in terms of higher yield and lower nitrate leaching. This process minimizes the farmer faces when it has to make this decision. Previous studies concluded that the marginal economic return in site-specific managed zones was higher if

Table 4

Variable and uniform $\mathrm{N}$ application by zone., The same amount of $\mathrm{N}\left(50 \mathrm{~kg} \mathrm{~N} \mathrm{ha}^{-1}\right)$ was applied at sowing and different rates were applied at elongation.

\begin{tabular}{|c|c|c|c|c|}
\hline & $\begin{array}{l}\text { Total N } \\
\left(\operatorname{kg~N~ha} a^{-1}\right)\end{array}$ & $\begin{array}{l}\mathrm{dN}_{\text {leach }} \\
\text { (slope) }\end{array}$ & $\begin{array}{l}\text { Optim. MV } \\
\left(\mathrm{kg} \mathrm{N} \mathrm{ha}{ }^{-1}\right)\end{array}$ & Notes \\
\hline Zone 1 & $170(50+120)$ & 0.0011 & {$[300]$} & High risk $\left(\mathrm{dN}_{\text {leach }}\right)$ of increasing $\mathrm{N}$ leaching \\
\hline Zone 2 & $220(50+170)$ & 0.0008 & {$[200-250]$} & Low $\mathrm{N}$ leaching - High MV response to $\mathrm{N}$ \\
\hline Zone 3 & $200(50+150)$ & $4.10^{-5}$ & {$[150-200]$} & High $\mathrm{N}$ leaching - Low $\mathrm{dN}_{\text {leach }}-$ Low $\mathrm{MV}$ response to $\mathrm{N}$ \\
\hline Unif. $\mathrm{N}$ & $240(50+190)$ & $\mathrm{NA}^{\mathrm{a}}$ & $N A^{a}$ & Farmers' uniform management \\
\hline
\end{tabular}

\footnotetext{
a NA: Not applicable.
} 
a)

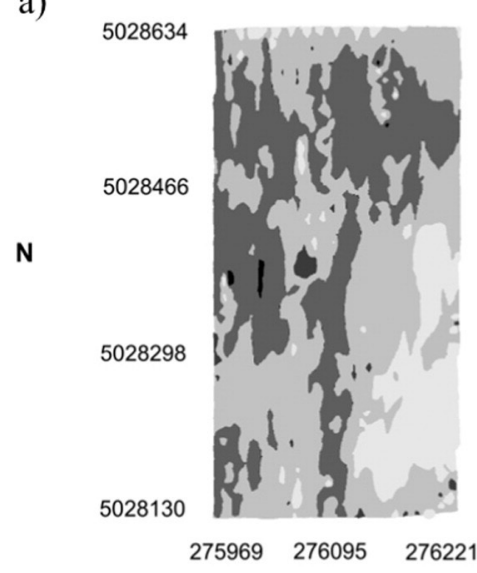

b)

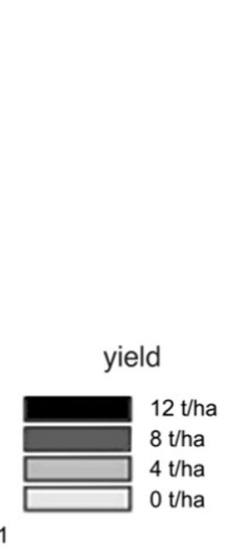

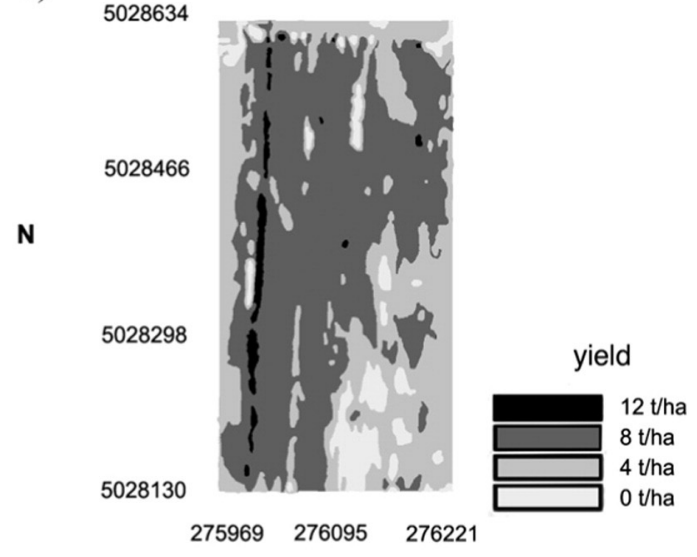

E

$\mathbf{E}$

Fig. 4. a-b. Spatial distribution of maize yield for the growing season 2007 (a) and 2008 (b).

spatial variability and temporal variability of crop $\mathrm{N}$ response in each zone was assessed (Basso et al., 2012, 2013, 2015). These results presented in this study are a further step from the analysis done by Basso et al. (2011a, 2013) where the trade-off for each uniform zone was analyzed, at different $\mathrm{N}$ applications levels. In this paper, we showed that through simulation modeling it is possible to identify the $\mathrm{N}$ fertilization rate that provides the highest economic return while at the same time providing the lowest negative environmental impact.

The success of variable $\mathrm{N}$ application rates in each zone remains however a function of the size of the zone and its response to a variable $\mathrm{N}$ fertilization. More in particular, in this study Zone 1 showed a marked response of revenue increase (Fig. $3 \mathrm{c}$ ) to variable $\mathrm{N}$ application but exhibited the lowest absolute yield (Fig. 3a). On the other end, it showed also a pronounced response of $\mathrm{N}$ leaching increase to $\mathrm{N}$ and the highest risk to $\mathrm{N}$ leaching (Fig. 3b, d). This zone is characterized by sandy soil (Table 2) and the application of business-as-usual $240 \mathrm{~kg} \mathrm{~N} \mathrm{ha}^{-1}$ would obviously have implications for increased $\mathrm{N}$ leaching, even during the season (Fig. 6). For these reasons, the selected $\mathrm{N}$ rate was deeply reduced ( $\left.170 \mathrm{~kg} \mathrm{~N} \mathrm{ha}^{-1}\right)$ in comparison to the business-as-usual practice. Zone 3 showed a medium response of yield increase to variable $\mathrm{N}$ application, and exhibited the highest absolute yield, but a negative response to variable $\mathrm{N}$ rate in terms of net income. Contrarily to Zone 1 , Zone 3 showed no particular risk to increase $\mathrm{N}$ leaching more than proportionally to the $\mathrm{N}$ rate applied in field $\left(\mathrm{dN}_{\text {leach }}\right.$ close to zero - Table 3$)$, but the higher yield were negatively offset by the highest simulated leached amount (Fig. 3b). The soil in Zone 3 is a clay loam and, while $\mathrm{N}$ that is not taken up by the crop from the soil increased the risk of leaching post-harvest, the residence time of $\mathrm{N}$ in the soil is greater than in the two other zones due to soil texture. Considering these facts, within the range of $\mathrm{N}$ rate that maximized farmers' incomes (Table 3), we selected the highest value of $200 \mathrm{kgN} \cdot \mathrm{ha}^{-1}$. Finally, based on the model simulations, Zone 2 had an intermediate response in terms of yield and net revenue increase to increasing rates of $\mathrm{N}$. It also had the lowest leached $\mathrm{N}$ and a reasonable risk to $\mathrm{N}$ leaching increase. For these reasons, the highest rate out of the three zones was recommended for Zone $2\left(220 \mathrm{~kg} \mathrm{~N} \mathrm{ha}^{-1}\right)$, yet being lower than the business-as-usual practice of $240 \mathrm{~kg} \mathrm{~N}^{-1}$.

The implementation of the predetermined rates was evaluated over two successive years. Both Zone 1 and Zone 3 showed a decrease in maize yield with the adoption of variable rates of $\mathrm{N}$ fertilization. Zone 1 showed an increase in net income and a reduction of the soil $\mathrm{N}-$ $\mathrm{NO}_{3}^{-}$content compared to business-as-usual management. Zone 3 was characterized by a reduction of the incomes, balanced however by a reduction in observed content of $\mathrm{N}-\mathrm{NO}_{3}^{-}$in the soil solution (Fig. 5) and in the averaged expected simulated $\mathrm{N}$ leaching (Fig. 6). While Zone 2 did not exhibit significant changes in observed yields when performing variable rate management, the reduced amount of $\mathrm{N}$ used led to significantly higher net incomes. Nevertheless, Zone 2 was characterized by lower content of $\mathrm{N}_{-} \mathrm{NO}_{3}^{-}$in the soil solution under the business-asusual management. Observations (Fig. 5) suggested that a lower rate should have been considered for this zone. However, the spatial dispersion of the two areas considered for Zone 2 trials could also have had a deep impact on these particular results.

Overall, when practicing site-specific management of $\mathrm{N}$ fertilization, the geometrical average of incomes at the field level were found to be higher and the global content of soil $\mathrm{N}^{-\mathrm{NO}_{3}^{-}}$were found to be lower compared to business-as-usual management. $\mathrm{N}$ fertilizer rates defined a priori with the use of crop models were proven to be relevant with

Table 5

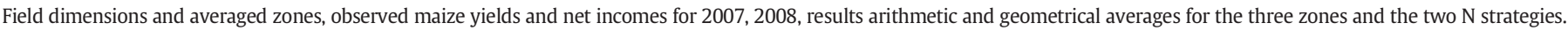

\begin{tabular}{|c|c|c|c|c|c|c|c|c|c|}
\hline & \multirow[t]{2}{*}{ Nfer $\left(\mathrm{kg} \mathrm{N} \mathrm{ha}^{-1}\right)$} & \multirow[t]{2}{*}{ Area (ha) } & \multirow{2}{*}{$\begin{array}{l}\mathrm{A}_{\mathrm{Z}} \text { (ha) } \\
\text { Average }\end{array}$} & \multicolumn{3}{|c|}{$\mathrm{Y}_{\mathrm{M}}\left(\mathrm{t} \mathrm{ha}^{-1}\right)$} & \multicolumn{3}{|c|}{$\mathrm{NI}\left(€ \mathrm{ha}^{-1}\right)$} \\
\hline & & & & 2007 & 2008 & Average & 2007 & 2008 & Average \\
\hline Zone 1 var. N & 170 & 1.89 & 1.89 & 4.3 & 6.6 & 5.4 & 422 & 732 & 617 \\
\hline Zone 2 var. $\mathrm{N}$ & 220 & 3.71 & 3.08 & 7.1 & 10.2 & 8.6 & 753 & 1172 & 963 \\
\hline Zone 3 var. N & 200 & 1.93 & 1.83 & 7.4 & 9.9 & 8.7 & 813 & 1150 & 981 \\
\hline Average & - & - & - & - & - & 7.58 & - & - & 840 \\
\hline GeomAvg & - & - & - & - & - & 7.76 & - & - & 861 \\
\hline Zone 1 unif. $\mathrm{N}$ & 240 & 1.89 & 1.89 & 4.3 & 7.3 & 5.8 & 357 & 762 & 559 \\
\hline Zone 2 unif. $\mathrm{N}$ & 240 & 2.45 & 3.08 & 6.7 & 9.8 & 8.3 & 681 & 1099 & 890 \\
\hline Zone 3 unif. $\mathrm{N}$ & 240 & 1.73 & 1.83 & 8.2 & 11.1 & 9.6 & 883 & 1275 & 1079 \\
\hline Average & - & - & - & - & - & 7.90 & - & - & 843 \\
\hline GeomAvg & - & - & - & - & - & 7.95 & - & - & 849 \\
\hline
\end{tabular}




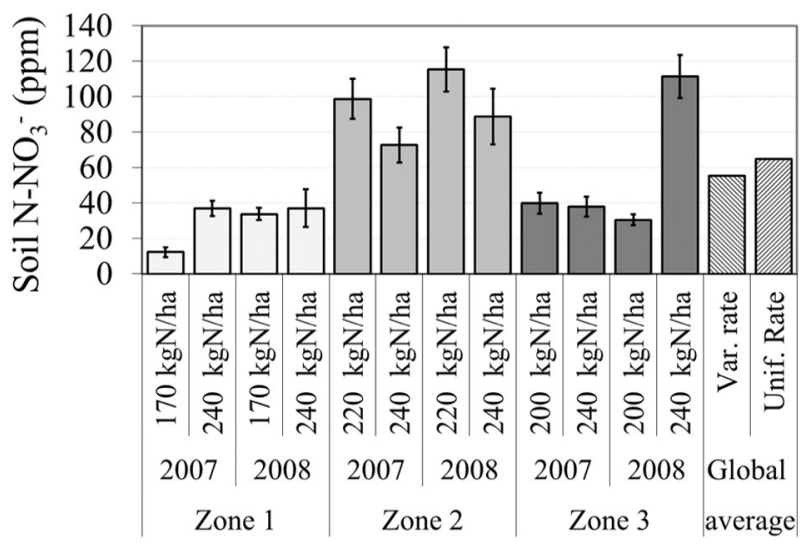

Fig. 5. Soil N-NO${ }_{3}^{-}$content (in ppm) measurements. Results are reported as the averages for variable and uniform rates, and individual results obtained under the different zones, during the crop seasons 2007 and 2008.

measures performed a posteriori. This study showed that crop simulation models can help farmers to make decisions about the optimal rate of fertilizer application within management zones. The trade-off between net income and $\mathrm{N}$ leaching clearly showed that uniform $\mathrm{N}$ application was not efficient, neither from the economic nor from the environmental point of view (Basso et al., 2011a, 2011b; Dumont et al., 2015b). Results of this study suggest that it is definitely not sustainable to use a fixed $\mathrm{N}$ rate for the entire field when considering the environmental constraints of the EU Nitrate directive (EEC, 1991).

Another problem with higher $\mathrm{N}$ fertilization rates is the association of nitrous oxide $\left(\mathrm{N}_{2} \mathrm{O}\right)$ emissions from agricultural systems to climate change (Robertson and Goffman, 2007). Therefore, a trade-off between $\mathrm{N}_{2} \mathrm{O}$ emissions, loss of nitrate through leaching, $\mathrm{N}$ fertilizer management practices, and crop yield has to be considered for each uniform zone when planning to apply variable $\mathrm{N}$ rates. The choice of an appropriate $\mathrm{N}$ rate for each zone, that is the most manageable commodity helps reduce environmental pollution from greenhouse gas emissions and $\mathrm{N}$ leaching while maintaining economic viability for farmers.

\section{Conclusions}

This study showed with field observations that environmental and economic benefits can simultaneously be achieved using variable $\mathrm{N}$ fertilization. Through a sophisticated procedure that links crop modeling with geospatial sciences, this study underlined the critical role of tradeoff between yield production and environmental outcomes and demonstrated how nitrogen management can be optimized to increase profit and reduce environmental impact. Spatial soil and yield information were successfully used for identifying uniform management zones.

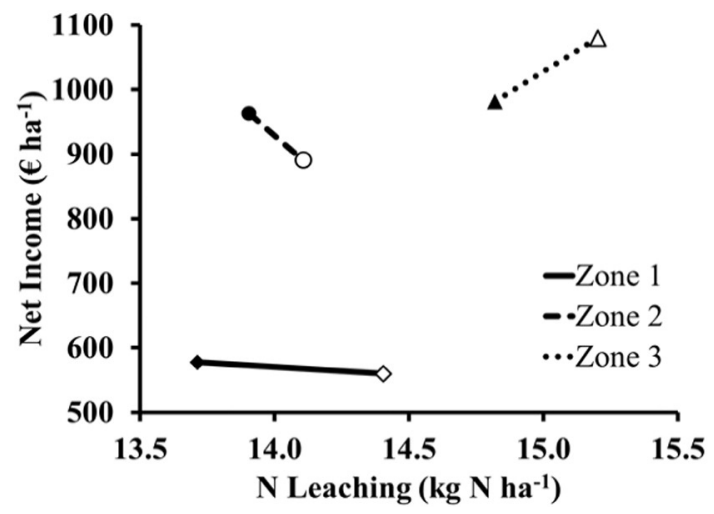

Fig. 6. Relationship between observed net return and simulated $\mathrm{N}$ leaching for Zone 1 (diamonds), Zone 2 (circles), and Zone 3 (triangles) for variable (black symbols) and uniform (white symbols) $\mathrm{N}$.
The use of a crop simulation model to account for the soil-plantatmosphere system interaction over space and time, helped select the proper amount of $\mathrm{N}$ to apply in order to minimize $\mathrm{N}$ leaching in each zone, without detrimentally impacting farmers revenues.

Research should focus on deepening the knowledge of soil-plantatmosphere interactions at a spatial and temporal scale, and to extrapolate those findings beyond a single farm to watershed or county levels. One the advantages of the approach developed in this paper lies precisely in the use of crop models, which allow to deal with other crop and soil management techniques that impacts $\mathrm{N}$ balance.

In conclusion, understanding spatial and temporal interactions between soil-plant-atmosphere is very important for a successful implementation of site-specific $\mathrm{N}$ management. Through the deployment of such a global approach and the subsequent validation via measurements, this research demonstrated that the agricultural systems of the Nitrate Vulnerable Zones would be both economically profitable and environmentally sustainable under site-specific management of $\mathrm{N}$ fertilization.

\section{Acknowledgments}

This study was partly supported by Veneto Agricoltura Regional Project "Agricoltura di precisione e conservativa"; funding for Basso and Dumont were provided by the USDA-NIFA Award no. 2015-6800723133 and 2011-68002-30190. Any opinions, findings, and conclusions or recommendations expressed in this publication are those of the authors and do not necessarily reflect the views of USDA. The funders had no role in study design, data collection and analysis, decision to publish, or preparation of the manuscript. The authors wish to thank Anne Stanton for her technical support.

\section{References}

Basso, B., Ritchie, J.T., 2015. Simulating crop growth and biogeochemical fluxes in response to land management using the SALUS model. In: Hamilton, S.K., Doll, J.E. Robertson, G.P. (Eds.), The Ecology of Agricultural Landscapes: Long-term Research on the Path to Sustainability. Oxford University Press, New York, NY USA, pp. 252-274.

Basso, B., Bertocco, M., Sartori, L., Martin, E.C., 2007. Analyzing the effects of climate variability on spatial patterns of yield in a maize-wheat-soybean rotation. Eur. J. Agron. 26, 82-91.

Basso, B., Cammarano, D., Troccoli, A., Chen, D., Ritchie, J.T., 2010. Long-term wheat response to nitrogen in a rainfed Mediterranean environment: field data and simulation analysis. Eur. J. Agron. 33, 132-138.

Basso, B., Ritchie, J.T., Cammarano, D., Sartori, L., 2011a. A strategic and tactical management approach to select optimal $\mathrm{N}$ fertilizer rates for wheat in a spatially variable field. Eur. J. Agron. 35, 215-222.

Basso, B., Sartori, L., Bertocco, M., Cammarano, D., Grace, P.R., 2011b. Economic and environmental evaluation of site-specific tillage in a maize crop in NE Italy. Eur. J. Agron. 35, 83-92.

Basso, B., Sartori, L., Cammarano, D., Fiorentino, C., Grace, P.R., Fountas, S., Sorensen, C.A., 2012. Environmental and economic evaluation of $\mathrm{N}$ fertilizer rates in a maize crop in Italy: a spatial and temporal analysis using crop models. Biosys. Eng. 113, 103-111.

Basso, B., Cammarano, D., Fiorentino, D., Ritchie, J.T., 2013. Wheat yield response to spatially variable nitrogen fertilizer in Mediterranean environment. Eur. J. Agron. 51 65-70.

Basso, B., Fiorentino, C., Cammarano, D., Schulthess, U., 2015. Variable rate nitrogen fertilizer response in wheat using remote sensing. Precision Agric. (In press). DOI: 10.1007/s11119-015-9414-9

Batchelor, W.D., Basso, B., Paz, J.O., 2002. Examples of strategies to analyze spatial and temporal yield variability using crop models. Eur. J. Agron. 18, 141-158.

Bertocco, M., Basso, B., Sartori, L., Martin, E.C., 2008. Evaluating energy efficiency of sitespecific tillage in maize in NE Italy. Bioresour. Technol. 99 (15), 6957-6965.

Chang, J., Clay, D.E., Carlson, C.G., Reese, C.L., Clay, S.A., Ellsbury, M.M., 2004. Defining yield goals and management zones to minimize yield and nitrogen and phosphorus fertilizer recommendation errors. Agron. J. 96, 825-831.

Chiericati, M., Morari, F., Sartori, L., Ortiz, B., Perry, C., Vellidis, G., 2007. Delineating management zones to apply site-specific irrigation in the Venice lagoon watershed. In: Stafford, J.V. (Ed.), Precision Agriculture '07. Wageningen Academic Publishers, The Netherlands: Wageningen, pp. 599-606.

Dumont, B., Basso, B., Leemans, V., Bodson, B., Destain, J.P., Destain, M.F., 2013. Yield variability linked to climate uncertainty and nitrogen fertilisation. In: Stafford, J.V. (Ed.), Precision Agriculture '13. Wageningen Academic Publishers, The Netherlands: Wageningen, pp. 427-434. 
Dumont, B., Basso, B., Leemans, V., Bodson, B., Destain, J.P., Destain, M.F., 2014. Systematic analysis of site-specific yield distributions resulting from nitrogen management and climatic variability interactions. Precision Agric. 16, 361-384.

Dumont, B., Basso, B., Leemans, V., Bodson, B., Destain, J.P., Destain, M.F., 2015a. A comparison of within season yield prediction algorithms based on crop model behaviour analysis. Agric. Forest Meteorol. 204, 10-21.

Dumont, B., Basso, B., Bodson, B., Destain, J.P., Destain, M.F., 2015b. Climatic risk assessment to improve nitrogen fertilisation recommendations: a strategic crop modelbased approach. Eur. J. Agron. 65, 10-17.

European Economic Community, 1991. Council Directive of 12 December 1991 concerning the protection of waters against pollution caused by nitrates from agricultural sources (available at http://eur-lex.europa.eu/legal-content/EN/TXT/?uri= CELEX:31991L0676 verified November 2015).

Ferguson, R.B., Lark, R.M., Slater, G.P., 2004. Approaches to management zone definition for use of nitrification inhibitors. Soil Sci. Soc. Am. J. 67, 937-947.

Fridgen, J.J., Kitchen, N.R., Sudduth, K.A., Drummond, S.T., Wiebold, W.J., Fraisse, C.W. 2004. Management zone analyst (MZA): software for subfield management zone delineation. Agron. J. 96, 100-108.

Golden Software, 1995. Surfer mapping system. Version 6.0 for Windows. Golden Software Inc., Golden, CO.

Grace, P.R., Robertson, G.P., Millar, N., Colunga-Garcia, M., Basso, B., Gage, S.H., Hoben, J., 2011. The contribution of maize cropping in the Midwest USA to global warming: regional estimate. Agric. Systems 104, 292-296.

Grossman, R.B., Reinsch, T.G., 2002. Bulk density and linear extensibility. In: Dane, J.H., Topp, C.G. (Eds.), SSSA Book Series 5.4: Methods of Soil Analysis: Part 4 Physical Methods. Chapter 2 - The Solid Phase. Soil Science Society of America, Inc. Madison, Wisconsin, USA.

Klute, A., Dirkens, C., 1986. Hydraulic conductivity and diffusivity: laboratory methods. In: Klute, A. (Ed.), Methods of Soil Analysis - Part 1. Physical and Mineralogical Methods, second ed. SSSA/ASA Madison, WI, pp. 687-734.
Mulla, DJ.. 1991. Using geostatistics and GIS to manage spatial patterns in soil fertility. In: Kranzler, G. (Ed.), Proc. of the Automated Agricultural for the 21st Century. ASAE, Chicago, IL (December 1991., St. Joseph, MI, 16-17).

Pezzuolo, A., Basso, B., Marinello, F., Sartori, L., 2014. Using SALUS model for medium and long term simulations of energy efficiency in different tillage systems. Appl. Math. Sci. 8 (129), 6433-6445.

Pierce, F.J., Nowak, P., 1999. Aspects of precision agriculture. Adv. Agron. 67, 1-85.

Ritchie, J.T., Gerakis, A., Suleiman, A., 1999. Simple model to estimate field-measured soil water limits. Trans. ASAE 42, 1609-1614.

Robert, P.C., 2002. Precision agriculture: a challenge for crop nutrition management. Plant Soil 247, 143-149.

Robertson, G.P., Goffman, P., 2007. Nitrogen transformations. In: Paul, E.A. (Ed.), Soil Microbiology, Ecology, and Biochemistry, third ed. Academic/Elsevier, New York, pp. 341-364.

Robertson, MJ., Llewellyn, RS, Mandel, R, Lawes, R, Bramley, R.G.V Swift L, Metz, N., O'Callaghan, C., 2012. Adoption of variable rate fertiliser application in the Australian grains industry: status, issues and prospects. Precision Agric. 13, 181-199.

Schepers, A.R., Shanahan, J.F., Liebig, M.A., Schepers, J.S., Johnson, S.H., Luchiari Jr., A., 2004. Appropriateness of management zones for characterizing spatial variability of soil properties and irrigated corn yields across years. Agron. J. 96, 195-203.

Software, G.D., 2009. GS +: Geostatistics for Environmental Sciences. Version 9.0. Gamma Design Software, Plainwell, MI, p. 44

Soil Survey Staff, 1999. Soil Taxonomy. second ed. USDA, National natural resources Conservation Service, Washington, DC.

Walkley, A., Black, I.A., 1934. An examination of the Degtjareff method for determining organic carbon in soils: effect of variations in digestion conditions and of inorganic soil constituents. Soil Sci. 63, 251-263. 